Article

\title{
The effect of the preheating on to properties of the wear resistant welds
}

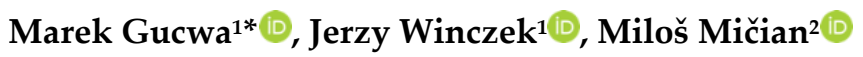 \\ 1 Czestochowa University of Technology \\ Prof. Jerzy Winczek, winczek@imipkm.pcz.pl \\ 2 University of Žilina, Slovakia \\ Prof. Miloš Mičian, milos.mician@fstroj.uniza.sk \\ * Correspondence: Marek Gucwa, Ph.D., mgucwa@spaw.pcz.pl
}

Received: 06.12.2019; Accepted: 28.02.2020

\begin{abstract}
Wear resistant welds are used in many industries when it is necessary to protect machine components and structures against wear caused by operating conditions. Often the main parameter determining the usefulness of these welds is high hardness reaching about 60 HRC. In many cases, after the surfacing process, a mesh of cracks is formed in the surface layer, which can affect the durability of the hard-wearing layers used. The paper presents the analysis of the influence of preheating up to $400{ }^{\circ} \mathrm{C}$ on the properties of welds and its effect on the number of cracks in the surface layer. The use of preheating allowed to reduce the number of cracks in the padding weld to 1 . The optimum heating temperature was $200{ }^{\circ} \mathrm{C}$, for which the number of cracks have been reduced and the lowest wear was recorded.
\end{abstract}

Keywords: hardfacing; cracks; wear; hardness; structure

\section{Introduction}

The use of hardfacing with the use of self-shielding cored wires allows for an economical way to increase the durability of surfaces protected in this way. The surfacing techniques and modern additional materials allow obtaining layers of e.g. chromium cast iron with numerous carbides on a non-alloy steel substrate. In this way, surfacing can compete with wear-resistant elements made, for example, using

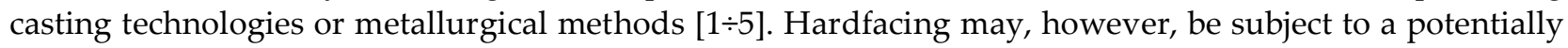
large number of welding Imperfections, defects [6], which may reduce the durability of the padding welds produced. Imperfections that occur most often during hardfacing with the use of self-shielding cored wires are cracks, numerous gas pores and spattering. These imperfections may affect the padding weld properties in different ways and e.g. spatter causes significant losses in the material, which reduces the efficiency of the welding process. The spatter itself results from the arc burn characteristics using cored wires, in which arc a drop of liquid metal breaks away from the end of the electrode randomly and usually not in the axis of the wire but from its lateral surface. Bubbles and gas pores, as voids, reduce the wear resistance of welds and are mainly due to the high cooling rate and low volume of the weld pool, which may prevent complete degassing of the padding weld. In the case of surfacing with materials with a carbon content similar to that in S235 steel, there are no cracks in the welds, but the structure of these layers is low in carbides and has a much lower hardness [7]. Cracks in hard high-carbon welds are oriented perpendicular to the direction of surfacing and when using unalloyed steels on the ground, such as S235, they are braked around the fusion line. They can be treated as a factor allowing to reduce the state of stress in the produced wear-resistant welds [8]. This is desirable, but in some applications, a large number of cracks can accelerate wear processes. With the occurring impact loads, the existing cracks can promote the detachment of large pieces of the weld and thus accelerate the wear of e.g. wear plates. Also emerging microcracks are conducive to faster wear of the surfaced layers [9].

The purpose of this work was to determine the possibility of reducing the number of cracks in wearresistant welds by preheating the base material prior to surfacing and the effect of preheating on the performance of the resulting hardfacing. 


\section{Research materials and methods}

The basic material in the form of a S235JR flat bar with a hardness of $140 \mathrm{HV}$ was used in studies of the effect of preheating on the properties of padding welds. The prepared samples with dimensions of $80 \times 200 \times 8 \mathrm{~mm}$ were surfaced with HARDFACE BNC self-shielding cored wire with a diameter of $1.2 \mathrm{~mm}$. The chemical composition of the wire is shown in table I. According to the manufacturer's data, it is a wire with very high wear resistance, moderate impact strength and hardness $64 \div 68$ HRC [8]. The MAGOMIG 402 device was used for surfacing. In order to reduce the spatter that often occurs during welding with selfshielding cored wires, M21 shielding gas was used in accordance with PN-EN ISO 14175. The surfacing parameters and sample designation are given in table II. Based on the preliminary tests, the pre-heating temperatures were determined, for which single-pass surfacing with straight beads was performed with an overlap of $30 \%$. To ensure a repeatable surfacing speed, the PRO DC-20 welding carriage was used. Preheating prior to welding was carried out by means of oxy-acetylene flame heating.

Table I. Chemical composition of the cored wire according to the manufacturer data [10] and the base material

\begin{tabular}{ccccccc}
\hline & & \multicolumn{4}{c}{ Chemical composition, wt. $\%$} \\
& C & Mn & Si & Cr & Nb & B \\
\hline HARDFACE & 2.5 & 2 & 0.6 & 11.5 & 5 & 2.2 \\
S235JR & 0.22 & 1.10 & $0.10 \div 0.35$ & - & - & - \\
\hline
\end{tabular}

Table II. The parameters of the hardfacing

\begin{tabular}{|c|c|c|c|c|c|}
\hline \multirow{2}{*}{ Parameters } & \multicolumn{5}{|c|}{ Sample designation } \\
\hline & 1 & 2 & 3 & 4 & 5 \\
\hline Current intensity I, A & \multicolumn{5}{|c|}{$210 \div 220$} \\
\hline Arc voltage U, V & \multicolumn{5}{|c|}{$28 \div 29$} \\
\hline Surfacing speed $v, \mathrm{~cm} / \mathrm{min}$ & \multicolumn{5}{|c|}{30} \\
\hline Length of electrode stick-out $l, \mathrm{~mm}$ & \multicolumn{5}{|c|}{25} \\
\hline Preheat temperature, ${ }^{\circ} \mathrm{C}$ & 20 & 100 & 200 & 300 & 400 \\
\hline
\end{tabular}

Samples after welding were subjected to visual tests, in accordance with PN-EN ISO 5817, to determine the number of cracks visible on the surface of the padding welds, the deflection was measured and the prepared specimens were evaluated on an optical microscope and subjected hardness tests. To determine wear resistance, the G65 tester and procedure A were used in accordance with ASTM G65.

\section{Research results}

\section{Visual tests}

Visual tests of the received padding welds after surfacing revealed numerous welding imperfections mainly in the form of transverse cracks on the padding welds and numerous spatters. Figure 1 presents photos of padding welds with visible cracks. According to the thesis, the number of cracks decreases with increasing preheating temperature. Table III presents changes in the number of cracks and deflection depending on the preheating temperature.

Table III. The quantity of the cracks and distortions depended on the preheating temperature

\begin{tabular}{ccc}
\hline Sample temperature, ${ }^{\circ} \mathbf{C}$ & Number of cracks & Deflection, $\mathbf{~ m m}$ \\
\hline 20 & 7 & 1 \\
100 & 5 & 2 \\
200 & 4 & 3.5 \\
300 & 4 & 4 \\
400 & 1 & 5 \\
\hline
\end{tabular}

\section{Metallographic tests}

The next stage of the research were metallographic and hardness tests of the padding welds. For metallographic analysis and hardness testing, the samples were cut using a refrigerated metallographic cutter. After grinding and polishing, the samples were digested in a solution of $3 \mathrm{~g} \mathrm{FeCl}_{3}, 10 \mathrm{~cm}^{3} \mathrm{HCl}, 90 \mathrm{~cm}^{3} \mathrm{C}_{2} \mathrm{H}_{5} \mathrm{OH}$. 
Microscopic tests were carried out, in accordance with PN-EN ISO 17639: 2013-12, on an Olympus GX51 metallographic optical microscope with Stream Start software enabling measurement of the geometrical size of welds on the images of metallographic specimens (Table IV). The hardness tests were also carried out on the same samples, in accordance with PN-EN SIO 6507-1: 2018-05, by the Vickers method with a load of $98.7 \mathrm{~N}$. The hardness was measured on the surface of the padding weld after previous grinding to a depth of $0.2 \mathrm{~mm}$. On cross-sections, the hardness was measured at a distance of about $2 \mathrm{~mm}$ from the surface of the sample in $0.5 \mathrm{~mm}$ steps. Figure 2 presents the results of structural studies. Images of structures were presented for each of the samples from the area near the face and from the center of the padding weld.

Table IV. The measured values of the geometry of the padding welds

\begin{tabular}{cccccc}
\hline Geometric parameter & $\mathbf{2 0}{ }^{\circ} \mathbf{C}$ & $\mathbf{1 0 0}^{\circ} \mathbf{C}$ & $\mathbf{2 0 0}{ }^{\circ} \mathbf{C}$ & $\mathbf{3 0 0}{ }^{\circ} \mathbf{C}$ & $\mathbf{4 0 0}^{\circ} \mathbf{C}$ \\
\hline Riser area, $\mathrm{mm}^{2}$ & 138.39 & 134.75 & 101.13 & 122.24 & 150.47 \\
Penetration area, $\mathrm{mm}^{2}$ & 53.98 & 45.94 & 55.02 & 46.58 & 53.89 \\
Share of the base material, $\%$ & 27.92 & 25.42 & 35.24 & 27.59 & 26.39 \\
Height, mm & $3.54 \div 4.20$ & $3.80 \div 4.59$ & $2.10 \div 3.41$ & $3.54 \div 4.07$ & $4.07 \div 4.46$ \\
Depth of penetration, $\mathrm{mm}$ & $0.66 \div 2.10$ & $0.39 \div 2.10$ & $0.66 \div 1.84$ & $0.79 \div 1.97$ & $0.80 \div 1.84$ \\
Width, $\mathrm{mm}$ & 35.94 & 37.11 & 38.03 & 35.28 & 38.17 \\
\hline
\end{tabular}

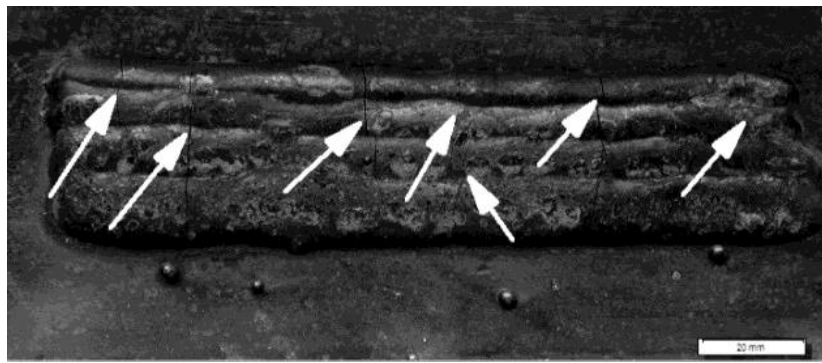

(a)

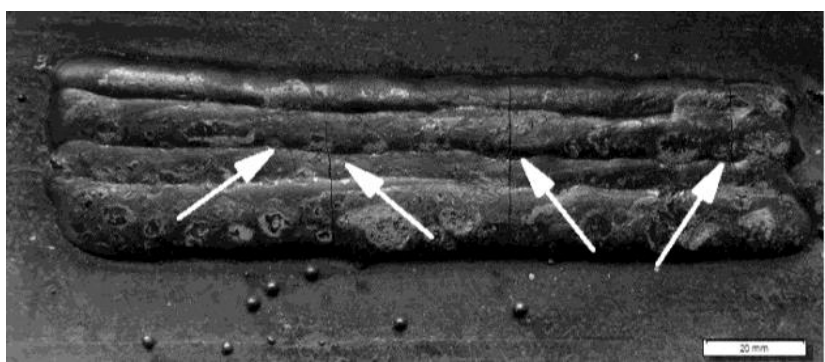

(c)

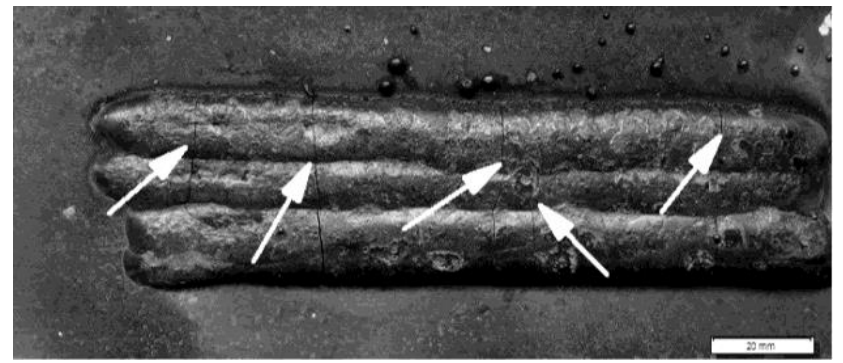

(b)

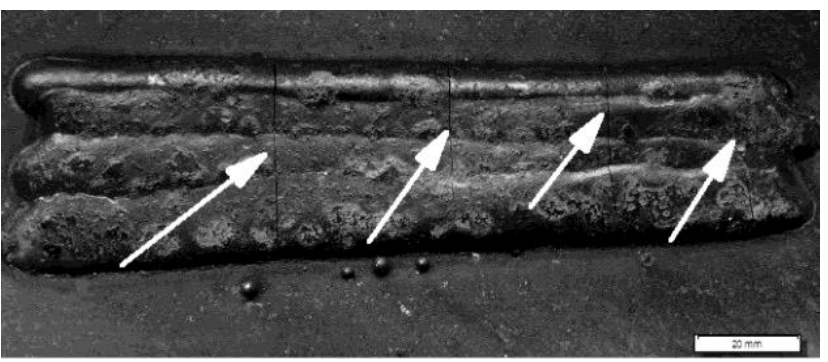

(d)

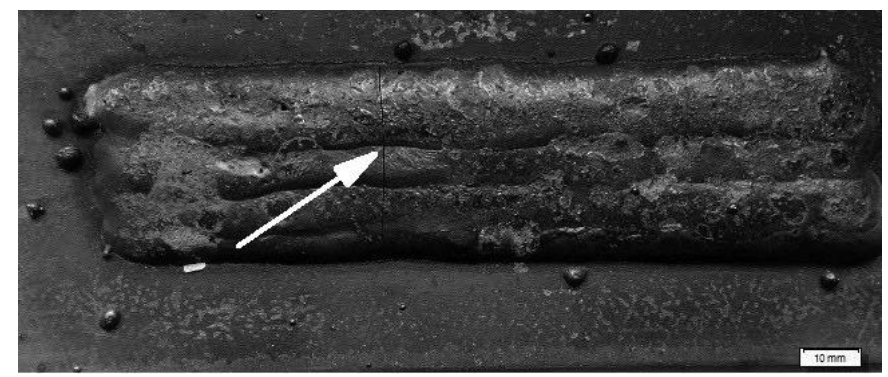

(e)

Fig. 1. The view of the surface of the padding welds with marked cracks: a) sample done without preheating, b) sample done with preheating up to $100{ }^{\circ} \mathrm{C}$, c) sample done with preheating up to $200{ }^{\circ} \mathrm{C}$, d) sample done with preheating up to $300{ }^{\circ} \mathrm{C}$, e) sample done with preheating up to $400{ }^{\circ} \mathrm{C}$ 
$20^{\circ} \mathrm{C}$

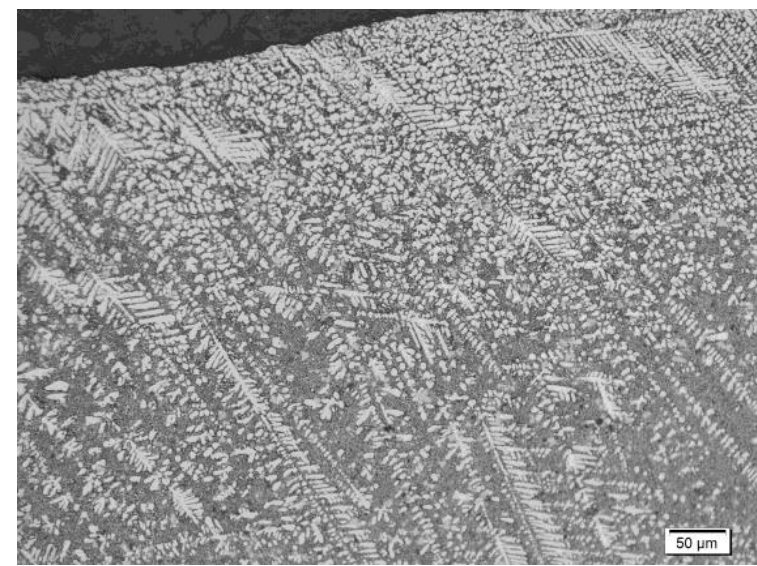

(a)

$100{ }^{\circ} \mathrm{C}$

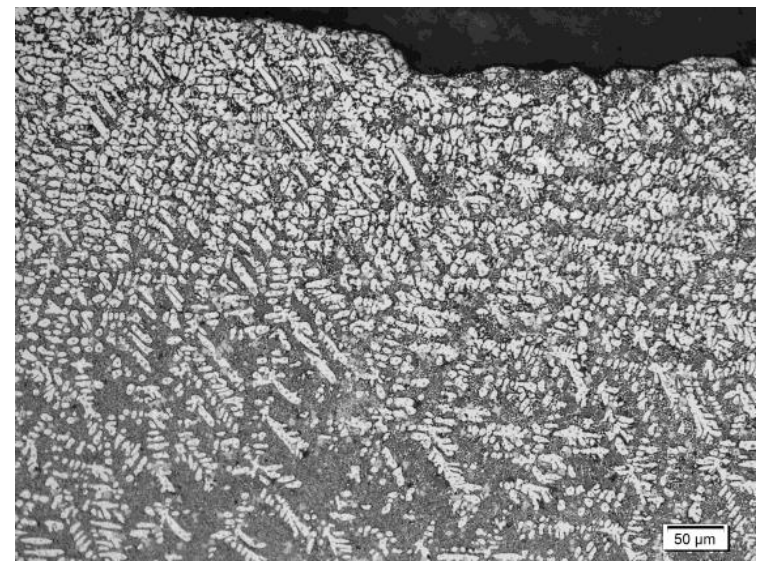

(c)

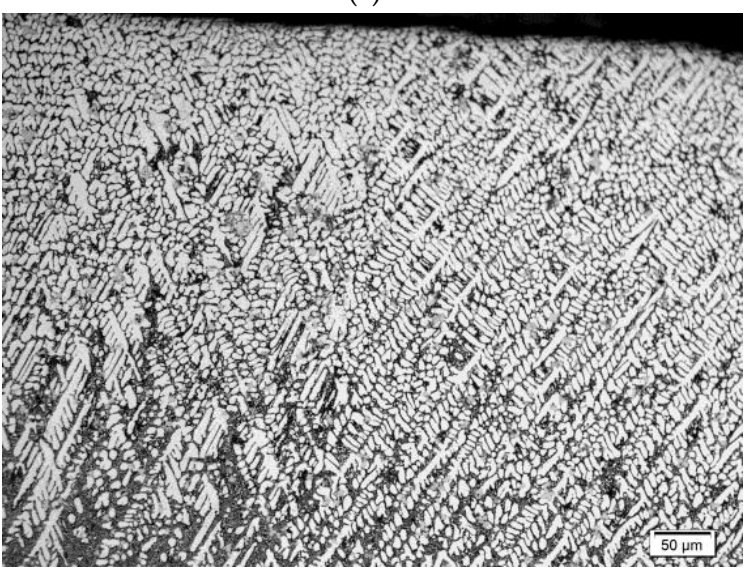

(e)

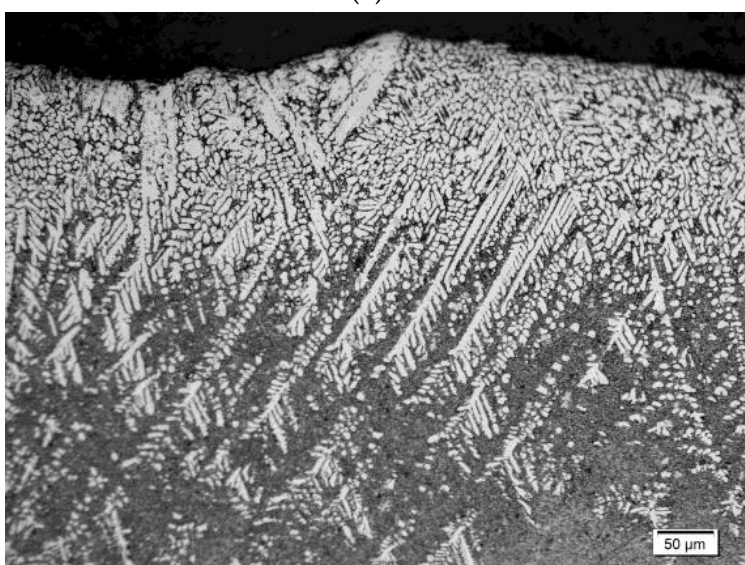

(g)

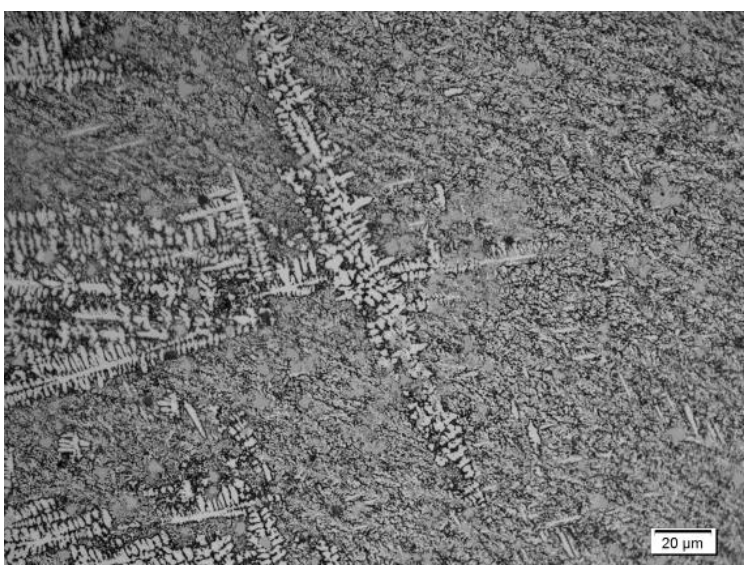

(b)

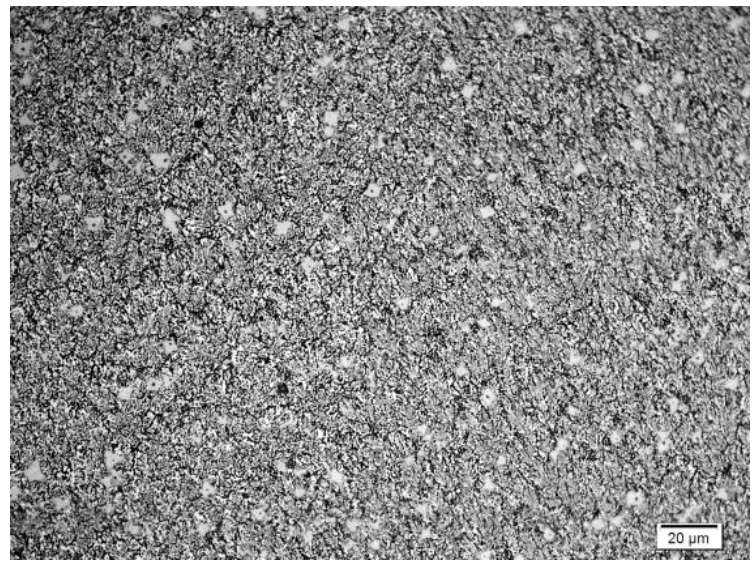

(d)

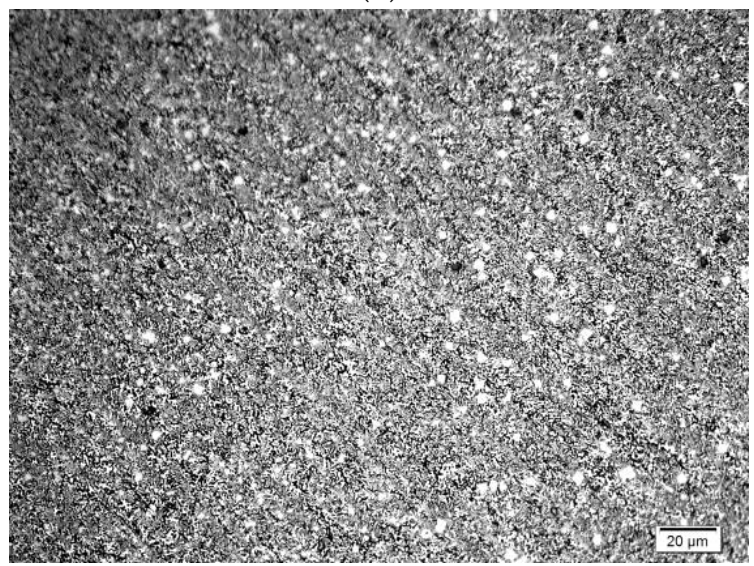

(f)

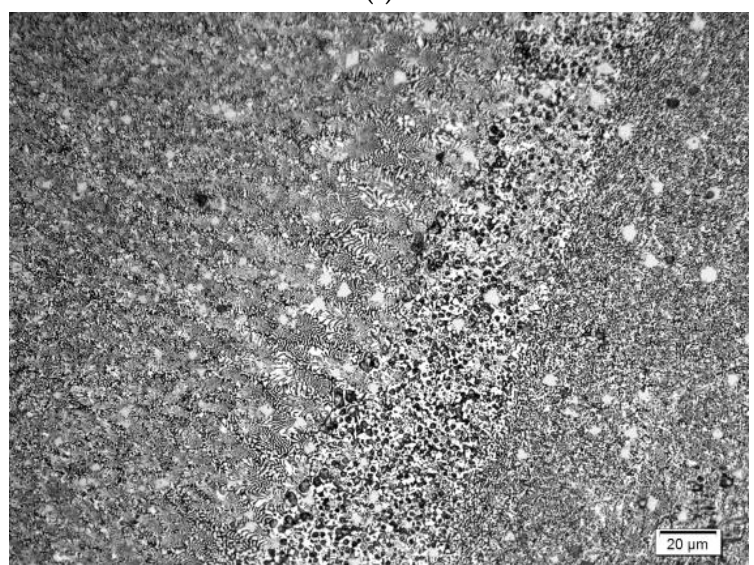

(h) 


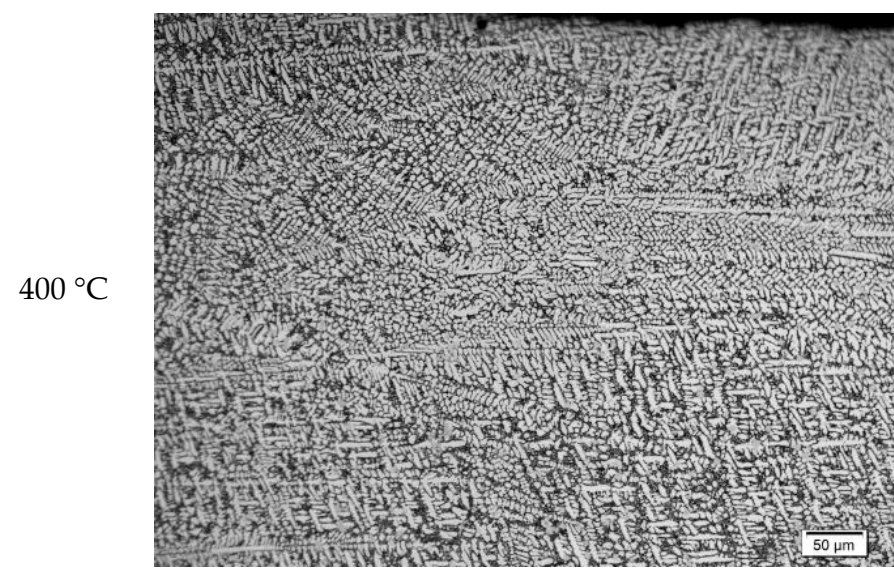

(i)

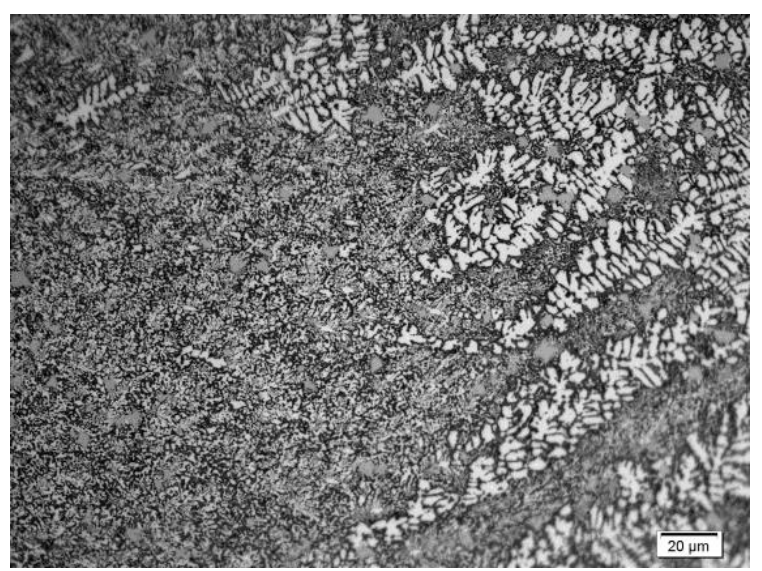

(j)

Fig. 2. The structures of the padding welds near the surface and in the middle of the high: a) structure close to surface of the sample done without preheating, b) structure in the middle of the sample done without preheating, c) structure close to surface of the sample done with preheating up to $100{ }^{\circ} \mathrm{C}$, d) structure in the middle of the sample done with preheating up to $100{ }^{\circ} \mathrm{C}$, e) structure close to surface of the sample done with preheating up to $200{ }^{\circ} \mathrm{C}$, f) structure in the middle of the sample done with preheating up to $200^{\circ} \mathrm{C}, \mathrm{g}$ ) structure close to surface of the sample done with preheating up to $300{ }^{\circ} \mathrm{C}$, h) structure in the middle of the sample done with preheating up to $300{ }^{\circ} \mathrm{C}$, i) structure close to surface of the sample done with preheating up to $300{ }^{\circ} \mathrm{C}, \mathrm{j}$ ) structure in the middle of the sample done with preheating up to $300^{\circ} \mathrm{C}$

Figures 3 and 4 present the hardness measurement results on the sample's surface and the cross-section of the padding weld.

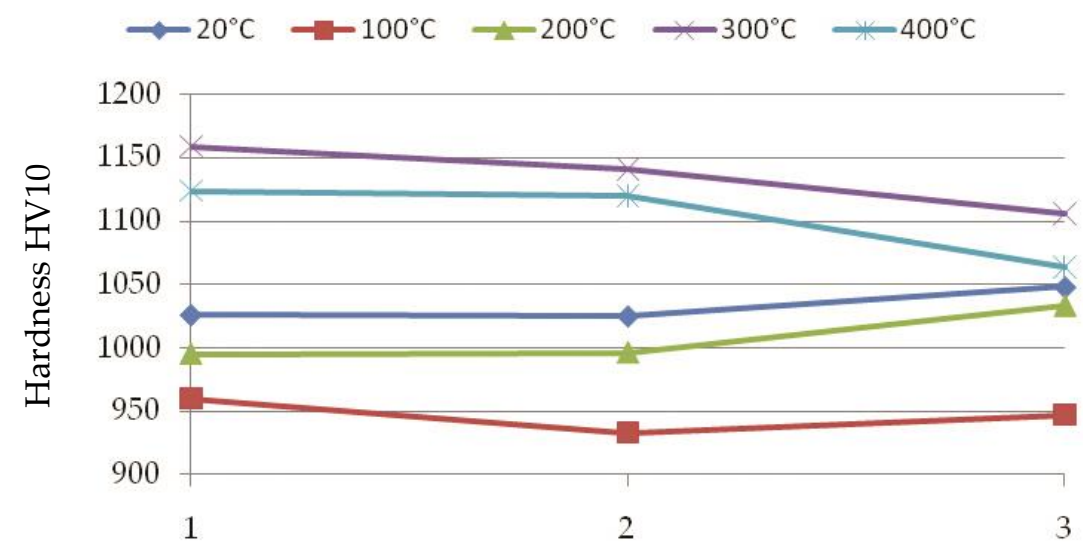

Measuring point number

Fig. 3. Hardness of the padding weld on the surface

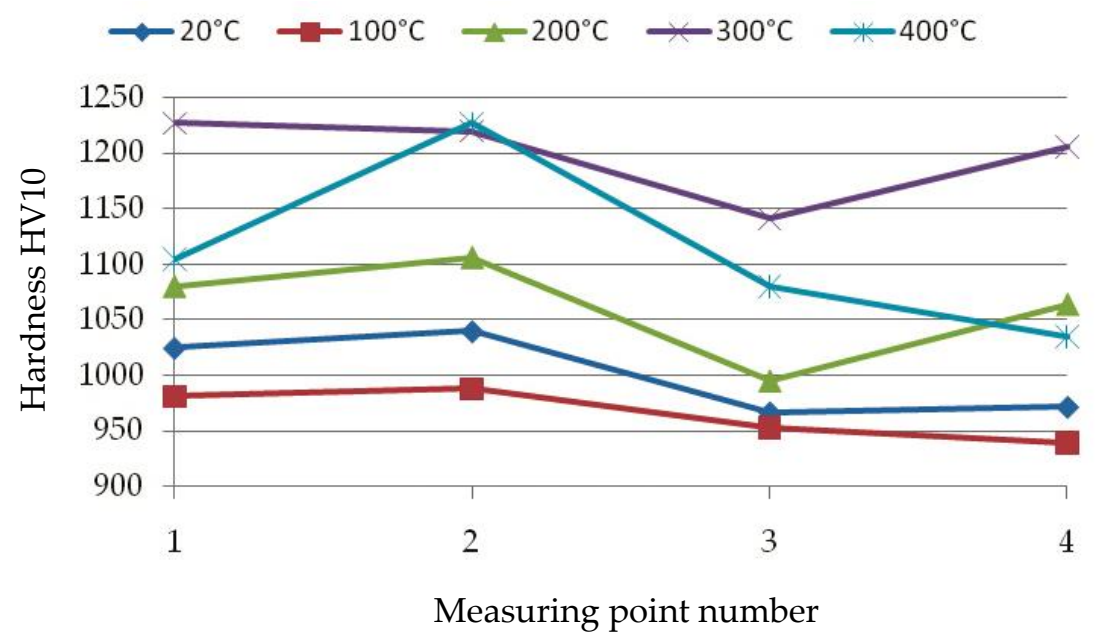

Fig. 4. Hardness of the padding weld on the cross section 


\section{Metal-mineral wear resistance tests}

Tests of resistance of the surfaced wear-resistant layers to metal-mineral wear were carried out in accordance with ASTM G65 [10] for procedure A. For tests, 75x30 mm samples were cut from the middle of padding welds, which were then ground to obtain an even surface. Before each consumption test, the samples were weighed on an electronic balance with an accuracy of $0.001 \mathrm{~g}$ and then after the test and cleaning in a stream of compressed air. The test results are presented in table V.

Table V. The results of the wear test metal-mineral

\begin{tabular}{|c|c|c|c|c|}
\hline \multirow{2}{*}{$\begin{array}{c}\text { Heating temperature, } \\
{ }^{\circ} \mathrm{C}\end{array}$} & \multicolumn{2}{|c|}{ Mass of the sample, $g$} & \multirow{2}{*}{$\begin{array}{c}\text { Mass decrement, } \\
\mathrm{g}\end{array}$} & \multirow{2}{*}{$\begin{array}{c}\text { Volume loss, } \\
\text { mm }^{3}\end{array}$} \\
\hline & Before the test & After the test & & \\
\hline 20 & 155.557 & 155.533 & 0.024 & 3.117 \\
\hline 100 & 170.988 & 170.962 & 0.026 & 3.376 \\
\hline 200 & 166.553 & 166.531 & 0.022 & 2.857 \\
\hline 300 & 164.751 & 164.726 & 0.025 & 3.247 \\
\hline 400 & 164.304 & 164.270 & 0.034 & 4.415 \\
\hline
\end{tabular}

\section{Test results analysis}

Cracks in the transverse direction to the surfacing direction are a common phenomenon associated with hardfacing. Their presence is caused by the formation of hard structures in the padding weld, often exceeding the hardness of the base material several times. Welding stresses caused by large volume shrinkage of padding welds are an additional factor causing welds cracks [8]. The welds obtained confirmed the usefulness of preheating the base material in terms of reducing the number of cracks. Similar conclusions can be drawn from [11], in which preheating also allowed to reduce the total length of cracks per unit area. They could not be eliminated completely, but their number was reduced from 7 (Fig. 1a) to 1 crack (Fig. 1e). Increasing the preheating temperature to $400{ }^{\circ} \mathrm{C}$ had the desired effect of significantly reducing the number of cracks. This temperature seems to be the limit temperature for the phenomenon of cracking in the tested padding welds, because the lower values of the heating temperature $\left(100 \div 300{ }^{\circ} \mathrm{C}\right)$ were not very important in limiting the number of cracks. The mere elimination of cracks by surfacing with preheating, however, increased the amount of deformation (Table III) from 1 $\mathrm{mm}$ to $5 \mathrm{~mm}$. This can cause difficulties in obtaining the desired geometry of wear-resistant plates manufactured on an industrial scale. Data from table IV indicate a high variability of the surfacing process without a visible linear relationship between the preheating temperature and the measured parameters describing the padding weld's geometry. One can notice the increase in the height of the hardfacing with the increase in preheating temperature and a decrease in the maximum depth of penetration of the padding weld into the base material. For the sample heated to $200{ }^{\circ} \mathrm{C}$ the smallest hardfaced weld height and the highest degree of mixing of the hardfaced layer with the base material were measured, which, however, did not adversely affect the results of wear tests. This hardfaced weld had a relatively uniform structure near the face. Increasing the value of preheating temperature prior to surfacing changed the thermal conditions of crystallization of the forming hardfacing. This is visible in the obtained microstructure images shown in figure 2. The change in the crystallization rate is mainly visible near the surface of the hardfacing. Significant differences in the size of the zone rich in primary carbides and large differences in their morphology can be seen in this area. This is confirmed by the results of the study on the impact of surfacing conditions on the microstructure of layers surfaced with titanium carbides [12]. Appropriately selected surfacing current and preheating temperature allow to regulate the volume and morphology of carbide precipitations in the structure in a relatively wide range. Large primary chromium carbides, often of a coniferous nature [13] crystallized near the surface, which gradually break up in the central part of the deposit. Large niobium carbides are visible in this area surrounded by finely dispersive eutectic chromium carbides or again large chromium carbides in the areas of overlapping beads (Fig. $2 \mathrm{~h}$ and $2 \mathrm{j}$ ). The highest carbide density can be distinguished near the face for the hardfacing with preheating equal to $200{ }^{\circ} \mathrm{C}$. The structure of this padding weld is shown in Figure $2 \mathrm{e}$ and, in addition to the high density of primary carbides, is characterized by a greater orientation of the growth of carbide structures towards the surface. For other samples, this increase is more random. The variable amount of carbides and their different morphology is reflected in the hardness test results shown in figures 3 and 4 . The highest hardness was recorded for the hardfacing with preheating to $300{ }^{\circ} \mathrm{C}$. Near the surface of this hardfacing 
large primary chromium carbides dominate, which gives an average hardness of close to 1200 HV10. Comparing this to the hardness of the base material, you can see an increase in hardness of about 8 times. Large differences in hardness can be observed for a hardfacing with a heating up to $400{ }^{\circ} \mathrm{C}$, where the differences in hardness below the surface of the sample reach 60 Vickers units, and on the cross-section nearly 200 Vickers units.

From the point of view of wear resistance, under the conditions of the test, the most important is the correlation of hardness values and carbide morphology and their amounts near the surface. In [14], many surfaced panels were analyzed, among which panels with similar hardness differed significantly in terms of wear resistance. The paper [15] presents the results of research indicating the harmful effect of too much primary carbide on wear resistance. This confirms the need to take into account a much larger number of parameters describing a padding weld than just hardness. The test results on the G65 tester indicate an optimal preheating temperature prior to surfacing at $200{ }^{\circ} \mathrm{C}($ Table $\mathrm{V})$. The smallest wear of the surfaced layer was observed for this value of preheating temperature. The highest measured wear was observed for a sample with preheating to $400{ }^{\circ} \mathrm{C}$, which, despite the relatively highest hardness, was also characterized by the largest dispersion of hardness results, which was also confirmed by microstructure tests indicating its large diversity and random directions of carbide growth near the surface.

\section{Summary}

Based on the conducted research and analysis of the results, it can be stated that:

1. It is possible to reduce the number of cracks in wear-resistant padding welds by applying preheating prior to surfacing. The temperature of $400{ }^{\circ} \mathrm{C}$ makes it possible to reduce the number of cracks from 7 to 1 on the same length of the padding weld in comparison to the padding weld made without preheating.

2. The use of preheating prior to surfacing significantly increases the deformation of the surfaced plates, which in practice may limit the possibility of heating in industrial conditions. The increase in the deflection value is 5 times in this case.

3. The use of preheating prior surfacing can lead to a decrease in wear resistance despite limiting the number of cracks. Under the conditions of the test, the optimum preheat temperature is $200{ }^{\circ} \mathrm{C}$. It seems to be expedient to extend research to other types of wear.

4. Wear resistance under the ASTM G65 test is primarily due to the structure of the surfaced layer and its hardness. A large number of carbides oriented in the direction of heat dissipation improves the durability of the surface layer despite a similar number of cracks as for padding welds made at a lower preheating temperature, but differently oriented carbides in the structure.

Author Contributions: conceptualization M.G., J.W.; methodology M.G., M.M.; investigation M.G., J.W.; writing - original draft preparation M.G., M.M.; writing-review and editing M.G., M.M.; supervision J.W.;

Funding: This research received no external funding

Conflicts of Interest: The authors declare no conflict of interest.

\section{References}

[1] Pokusová M., Brúsilová A., Šooš L., Berta I., Abrasion wear behavior of high-chromium cast iron. Archives of Foundry Engineering, 2016, Vol. 16(2), 69-74. https://doi.org/10.1515/afe-2016-0028

[2] Kopyciński D., Piasny S., Kawalec M., Madizhanova A., The Abrasive wear resistance of chromium cast iron. Archives of Foundry Engineering, 2014, Vol. 14(1), 63-66. https://doi.org/10.2478/afe-2014-0015

[3] Szymura M., Czuprynski A., Różański M., Research on the properties of high chromium cast iron overlay welds deposited by tubular electrodes. Welding Technology Review, 2018, Vol. 90(10), 26-30.

https://doi.org/10.26628/wtr.v90i10.963

[4] Górka J., Czupryński A., Żuk M., Adamiak M., Kopyść A., Properties and structure of deposited nanocrystalline coatings in relation to selected construction materials resistant to abrasive wear. Materials, 2018, Vol. 11(7), 1184; https://doi.org/10.3390/ma11071184

[5] Okechukwu C., Dahunsi O. A., Ok P. K., Oladele I. O., Dauda M., Review on hardfacing as method of improving the servise life of critical components subjected to wear in service. Nigerian Journal of Technology, 2017,

Vol. 36(4), 1095-1103. https://doi.org/10.4314/njt.v36i4.15 
[6] Bęczkowski R., Gucwa M., Defects appearing in the surfacing layers of abrasion resistant. Archive of Foundry Engineering, 2016, Vol. 16(4), 23-28. https://doi.org/10.1515/afe-2016-0077

[7] Viňáš J., Janette Brezinová J., Greš M., Resistance of Cladding Layers Made by FCAW Method to Erosive Wear. Materials Science Forum, 2016, Vol. 862, 33-40. https://doi.org/10.4028/www.scientific.net/MSF.862.33

[8] Buchanan V. E., Solidification and microstructural characterisation of iron-chromium basedhardfaced coatings deposited by SMAW and electric arc spraying. Surface \& Coatings Technology, 2009, Vol. 203, 3638-3646. https://doi.org/10.1016/j.surfcoat.2009.05.051

[9] Hornung J., Zikin A., Pichelbauer K.,Kalin M.,Kirchgaßner M., Influence of cooling speed on the microstructure and wear behaviour of hypereutectic Fe-Cr-C hardfacings. Materials Science and Engineering: A, 2013, Vol. 576, 243-251. https://doi.org/10.1016/j.msea.2013.04.029

[10] Catalogue Welding Alloys.

[11] Chatterjee S., Pal T. K., Welded procedural effect on the performance of iron based hardfacing deposits on cast iron substrate. Journal of Materials Processing Technology, 2006, Vol. 173(1), 61-69. https://doi.org/10.1016/j.jmatprotec.2005.10.025

[12] Nagentrau M., Mohd Tobi A. L., Sambu M., Jamian S., The influence of welding condition on the microstructure of WC hardfacing coating on carbon steel substrate. International Journal of Refractory Metals $\mathcal{E}$ Hard Materials, 2019, Vol. 82, 43-57. https://doi.org/10.1016/j.ijrmhm.2019.03.029

[13] Chaidemenopoulos N. G., Psyllaki P. P., Pavlidou E., Vourlias G., Aspects on carbides transformations of Febased hardfacing deposits. Surface E Coatings Technology, 2019, Vol. 357, 651-661. https://doi.org/10.1016/j.surfcoat.2018.10.061

[14] Czupryński A., Kik T., Melcer M., Porównanie odporności na zużycie ścierne płyt trudnościeralnych. Welding Technology Review, 2018, Vol. 90(5), 28-36. https://doi.org/10.26628/ps.v90i5.893

[15] Correa E.O., N.G. Alcântara N.G., Valeriano L.C., Barbedo N.D., Chaves R.R., The effect of microstructure on abrasive wear of a Fe-Cr-C-Nb hardfacing alloy deposited by the open arc welding process. Surface E Coatings Technology, 2015, Vol. 276, 479-484. https://doi.org/10.1016/j.surfcoat.2015.06.026

(C) 2020 by the authors. Submitted for possible open access publication under the terms and conditions of the Creative Commons Attribution (CC BY) license (http://creativecommons.org/licenses/by/4.0/). 